\title{
TFG/ALK Extra Long Form Fusion Gene
}

National Cancer Institute

\section{Source}

National Cancer Institute. TFG/ALK Extra Long Form Fusion Gene. NCI Thesaurus. Code C101079.

A fusion gene ( $2.6 \mathrm{~kb})$ that results from a chromosomal translocation $\mathrm{t}(2 ; 3)(\mathrm{p} 23 ; \mathrm{q} 21)$

which fuses the 5 ' half of the TFG gene to the last 10 exons of the ALK gene. This rearrangement is associated with anaplastic large cell lymphoma. 